\title{
The Influence of Pier Stiffness Ratio on the Failure Modes of Masonry Structures
}

\author{
Yanru Wang, ${ }^{1,2}$ Xuegang Feng, ${ }^{3}$ and Bin $\mathrm{Fu}^{4}$ \\ ${ }^{1}$ Tongii University, Shanghai 200092, China \\ ${ }^{2}$ Wenzhou University, Wenzhou, Zhejiang 325035, China \\ ${ }^{3}$ Shandong Tongyuan Design Group Co. Ltd., Qingdao Branch, Qingdao, Shandong 266071, China \\ ${ }^{4}$ Wenzhou Design Group Co. Ltd., Wenzhou, Zhejiang 325001, China \\ Correspondence should be addressed to Yanru Wang; yanrupiaoyang@163.com
}

Received 20 February 2015; Accepted 15 April 2015

Academic Editor: Yanxue Wang

Copyright (C) 2015 Yanru Wang et al. This is an open access article distributed under the Creative Commons Attribution License, which permits unrestricted use, distribution, and reproduction in any medium, provided the original work is properly cited.

\begin{abstract}
Masonry structure is the main form of Chinese urban and rural housing construction structure. And heavy casualties and huge economic losses are caused by the damages of masonry structures in the previous destructive earthquake. So the failure modes of masonry structures are analyzed in the paper. ABAQUS software was used; and the Xuankou High School Student Dormitory of masonry structure in Yingxiu town, severely damaged under the Wenchuan earthquake, was taken for example. The influence of the stiffness ratio of pier between windows and spandrel on the failure modes of masonry structures is discussed. The results show that the failure modes in the earthquake could be changed by controlling the stiffness ratio. Suitable stiffness ratio helps proper design of masonry structures.
\end{abstract}

\section{Introduction}

Since the 5.12 Wenchuan earthquake in Sichuan, China, with a total of 7.79 million houses collapsed and 24.5 million houses damaged, by investigating the building structure damaged, scholars found that many of severe damaged or collapsed buildings were masonry structure building in earthquake disaster due to the unreasonable structural design, the poor construction quality, and so on. Meanwhile, some of masonry structures showed good seismic performance even in high-intensity area. Also it is found that although there are different degrees of damage on many masonry structures buildings, they did not collapse. This phenomenon causes people to pay attention to studies on seismic performance and structural failure mode. Previous studies of the masonry structure damage in the earthquake are most focused on the survey of damage phenomena and individual member's damage [1-6]; few scholars study the overall failure mode in destructive earthquake [7-9] and failure criteria for masonry [10-13]. In this paper, there is a more in-depth and quantitative description of the failure mode of masonry structures, such as the impact of the ratio of the horizontal lateral stiffness of pier between windows and the vertical stiffness of spandrel on the failure mode; and the analysis gives some meaningful conclusions.

\section{Finite Element Model of Masonry Structure Built}

For the comparative analysis of the impact of the ratio of the horizontal lateral stiffness of pier between windows and the vertical stiffness of spandrel on the failure mode, the Xuankou High School Student Dormitory of masonry structure in Yingxiu town was taken for example. The structure, a new masonry structure, was built in 2005 according to the Chinese design specifications. The structure has ring beams, lintels, and structural columns; and the floor is the slab floor. The building shown in Figure 1 was severely damaged in the Wenchuan earthquake.

Considering the performance limitation of the computer, the dimensions of the original structure, the Xuankou High School Student Dormitory, are simplified as follows. The impact of the stairwell on the overall seismic performance 


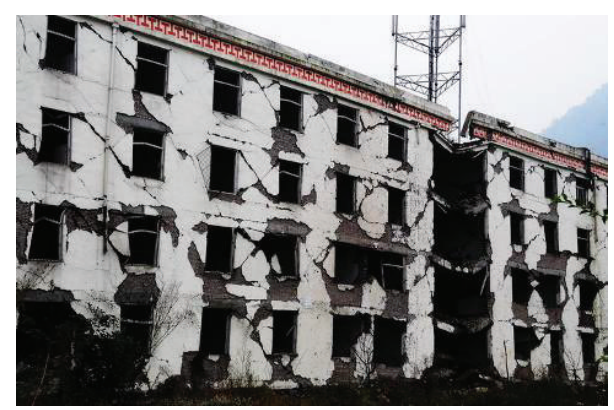

Figure 1: The Xuankou High School Student Dormitory.

of masonry structures is not discussed in this paper; so part of structure is considered in horizontal direction. The size of window openings is $1500 \mathrm{~mm} \times 1860 \mathrm{~mm}$, (width $\times$ height); the height of the window is $900 \mathrm{~mm}$; the size of the door openings is $1000 \mathrm{~mm} \times 2760 \mathrm{~mm}$; and the structure is the same as the original one in vertical direction. The plan diagram is shown in Figure 2. Due to the decrease of span in horizontal direction, the height of structure is also reduced. There are four floors and the height of floors is $3 \mathrm{~m}$. The strength class of brick masonry material is MU10; the strength class of mortar is M7.5; concrete strength grade of ring beams, structural columns, and slabs is C25; and reinforced steel is I grade.

Due to problems such as the heterogeneity of masonry structures, masonry material constitutive relationship, and the complexity of failure criteria, especially nonlinear analysis of masonry structure considered, there is no ideal finite element analysis software used for simulation of masonry structures. Taking into account the limitations of the computer performance and the macrosimulation analysis of failure mode for masonry structure focused on, the monolithic finite element model is used to simulate masonry structure; what is more, the material model is viewed as an isotropic homogeneous continuum model.

In this paper, ABAQUS software is used to build the finite element model of masonry structure. ABAQUS software is designed for nonlinear finite element analysis software. It is powerful engineering simulation finite element software to solve problems ranging from relatively simple linear static problems to many highly complex nonlinear problems [1416]. Based on two-step analysis of the static calculation and dynamic calculation, the material model masonry structures of piers and concrete comments are Concrete Damaged Plasticity models. A solid element of linear reduced integration unit (C3D8R) is used for piers and concrete comments. Flat reduced integration unit (SFM3D4R) is used for steel surface layer; and single precision arithmetic is used for nonlinear computational analysis. Tie constraint (binding constraints) in cell library is simulating the interaction between concrete structures masonry piers, ring beams, and structural columns without regard to the relative motion. In addition, taking into account Rachel steel between structural columns and piers at the actual structure and the contact surface to be made of horse teeth Croucher, it is assumed that the movements between structural columns and masonry piers are coupled
TABLE 1: The models.

\begin{tabular}{lcc}
\hline & The models & $\begin{array}{c}\text { The height of } \\
\text { spandrel }(\mathrm{m})\end{array}$ \\
\hline Model 1 & With structural columns & 0.9 \\
Model 2 & Without structural columns & \\
Model 3 & With structural columns & 1.2 \\
Model 4 & Without structural columns & \\
Model 5 & With structural columns & 0.6 \\
Model 6 & Without structural columns & \\
\hline
\end{tabular}

in order to replace the effects of pull binding of Rachel steel between structural columns and masonry piers.

For the comparative analysis of the impact of the ratio of the horizontal lateral stiffness of pier between windows and the vertical stiffness of spandrel on the failure mode, in this paper, six models are established. Three of them have structural columns; and three of them do not have structural columns. The material grade of models is the same; and the stiffness of spandrel is changed in the way of increasing or decreasing the height of spandrel by $300 \mathrm{~mm}$. The models are shown in Table 1; and the model images are shown in Figures $3,4,5,6,7$, and 8 .

\section{Failure Mode Analysis}

3.1. Loading Input. Each model was set up two-step analysis to calculate the structural response under seismic action. Two steps are used in the analysis of single-precision dynamic explicit solution. Explicit solution increment is set automatically. The first step to analyze the input and calculation is static loads. Static loads include the weight of the load and the load slab of $3 \mathrm{kN} / \mathrm{m}^{2}$ uniform loads. The second calculation step is seismic analysis. Each model is affected in two orthogonal horizontal ground motions. The ground motions come from Wenchuan earthquake database. The location of Lixian County ground motion and Wolong ground motion which is closer to Yingxiu town was used as the ground motion input. Taking into account the amount of computation, this paper processed and intercepted parts of the ground motion [17]. Ground motion parameters are shown in Table 2; and the time history curve or the FFT curve is shown in Figures 9, $10,11,12,13,14,15$, and 16 .

\subsection{The Stiffness Ratio of Pier between Windows and Spandrel.} For the comparative analysis of the impact of the stiffness ratio for pier between windows and spandrel on the failure mode, the horizontal lateral stiffness of pier between windows and the vertical stiffness of spandrel should be calculated under various conditions. Reinforced concrete structural columns and ring beam can effectively improve the rigidity and stability of masonry structure, improving deformation capacity of masonry structure. Meanwhile, the improvement of material strength and the geometry size of wall between the windows and spandrel can change the stiffness of masonry structure. Lateral piers stiffness of masonry structure without 


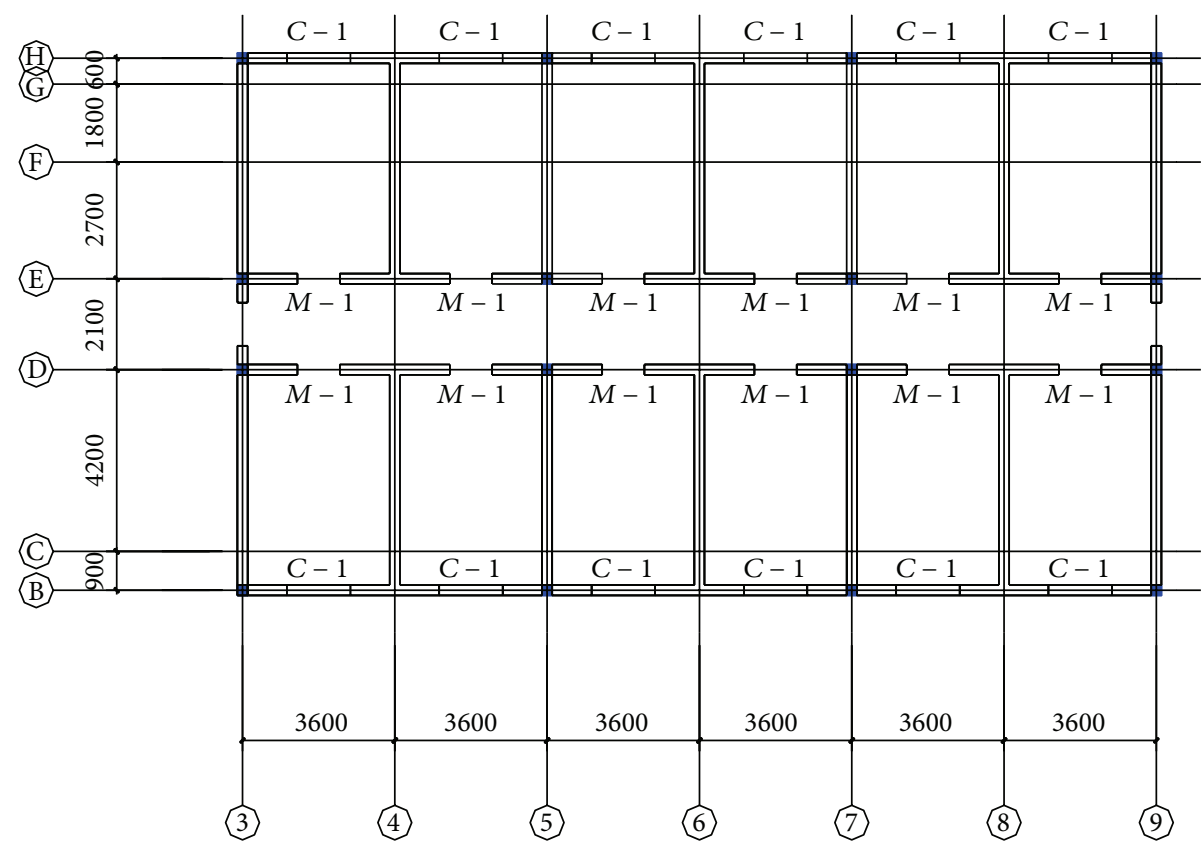

FIgURe 2: Plan diagram.

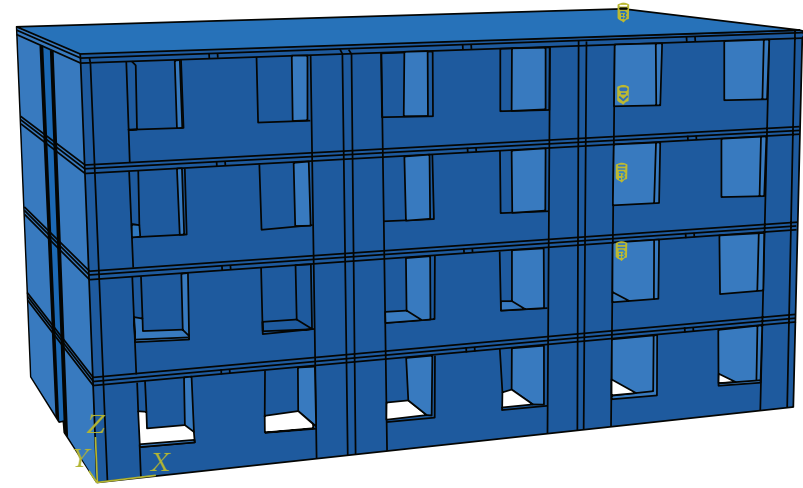

FIGURE 3: Model 1 with structural columns (0.9 m).

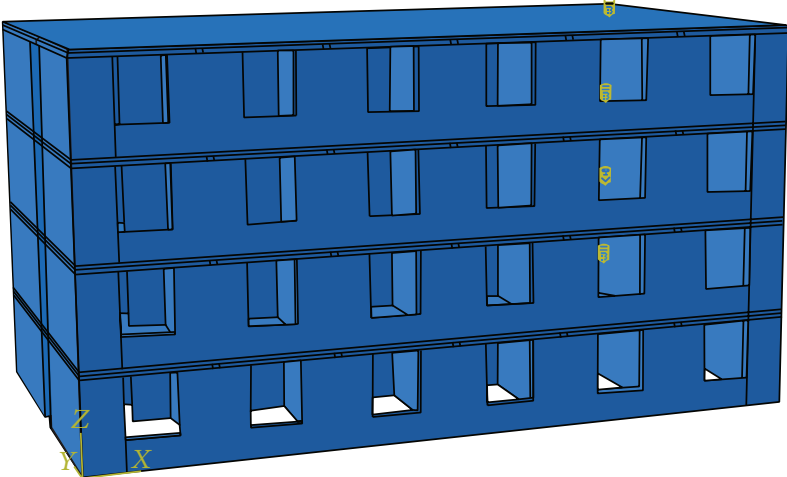

FIGURE 4: Model 2 without structural columns (0.9 m). 


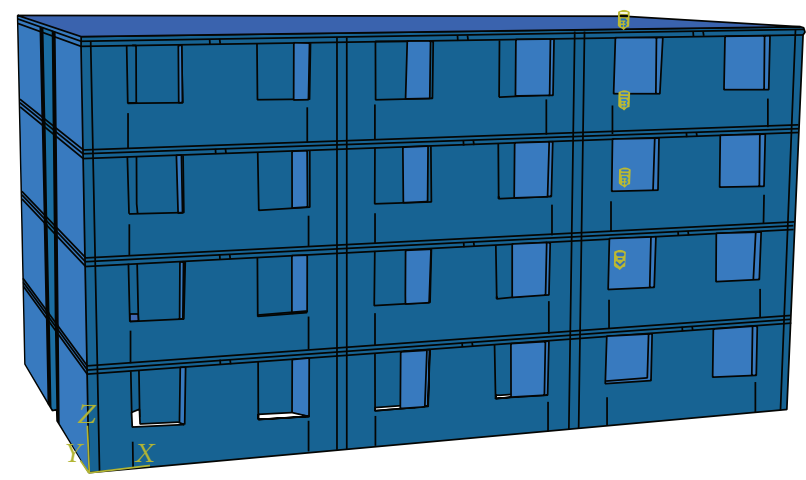

Figure 5: Model 3 with structural columns (1.2 m).

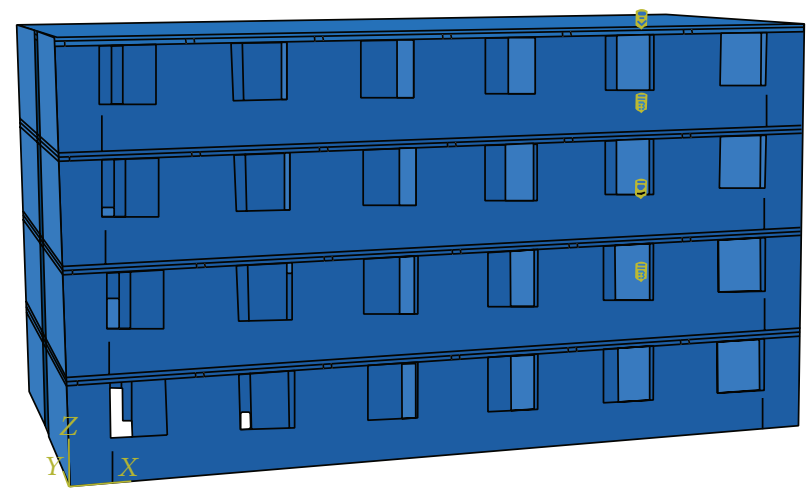

FIgURE 6: Model 4 without structural columns (1.2 m).

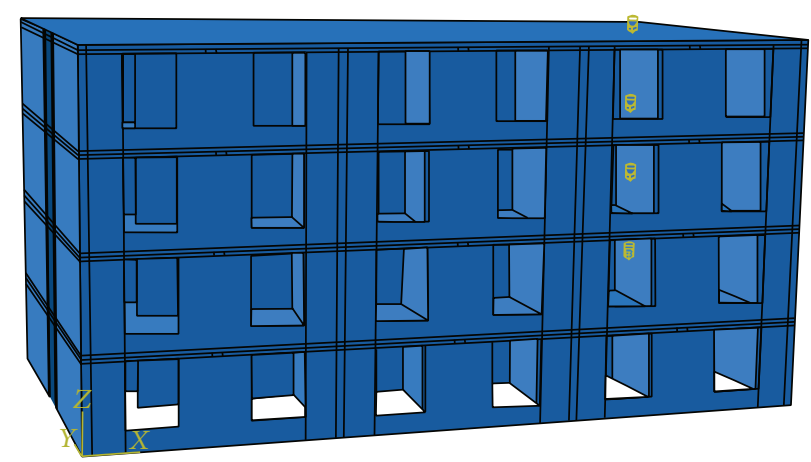

Figure 7: Model 5 with structural columns $(0.6 \mathrm{~m})$.

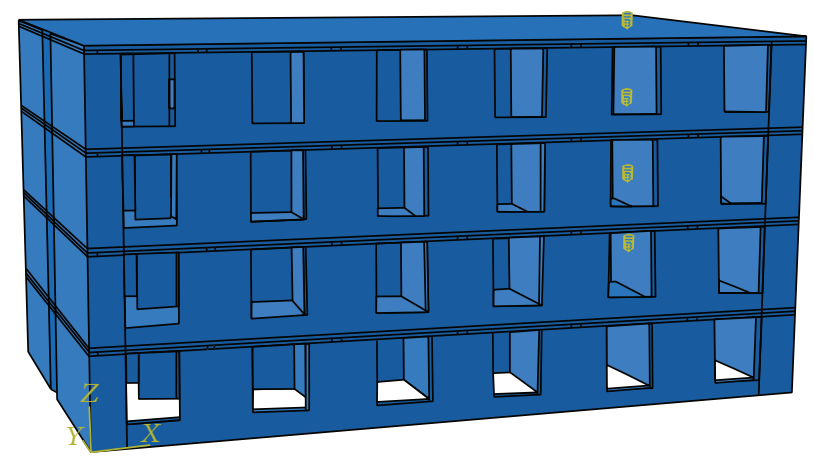

FIgURE 8: Model 6 without structural columns (0.6 m). 
TABLE 2: Ground motion parameters.

\begin{tabular}{|c|c|c|c|c|c|}
\hline \multirow{2}{*}{ Name of ground motions } & \multirow{2}{*}{ Duration (s) } & \multicolumn{2}{|c|}{ PGA $\left(\mathrm{cm} / \mathrm{s}^{2}\right)$} & \multicolumn{2}{|c|}{ Frequency $(\mathrm{Hz})$} \\
\hline & & $X$ & $Y$ & $X$ & Y \\
\hline Wolong ground motion & 13 & 957.7 & 648.5 & 2.3 & 2.3 \\
\hline Lixian county ground motion & 10 & 303.9 & 266.1 & 2.8 & 2.9 \\
\hline
\end{tabular}

TABLE 3: The stiffness of pier between windows and spandrel $\left(1 \times 10^{8} \mathrm{~N} / \mathrm{m}\right)$.

\begin{tabular}{|c|c|c|c|c|}
\hline & The models & Pier between windows & Pier beside windows & Spandrel \\
\hline Model 1 & With structural columns & 2.83 & 1.15 & \multirow{2}{*}{1.61} \\
\hline Model 2 & Without structural columns & 2.43 & 0.74 & \\
\hline Model 3 & With structural columns & 3.48 & 1.57 & \multirow{2}{*}{2.20} \\
\hline Model 4 & Without structural columns & 2.91 & 1.02 & \\
\hline Model 5 & With structural columns & 2.35 & 0.86 & \multirow{2}{*}{1.00} \\
\hline Model 6 & Without structural columns & 2.10 & 0.55 & \\
\hline
\end{tabular}

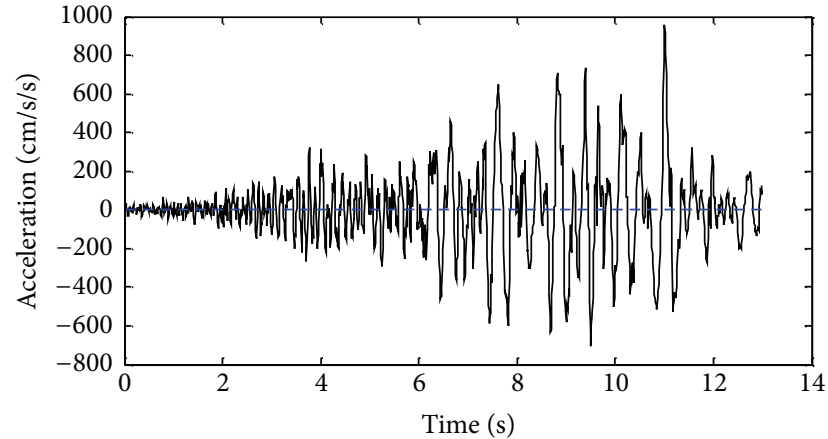

_ Peak: $957.70 \mathrm{~cm} / \mathrm{s} / \mathrm{s}$ at $11.01 \mathrm{~s}$

-. - Zeroline

Figure 9: The time history curve of Wolong ground motion in $X$ direction.

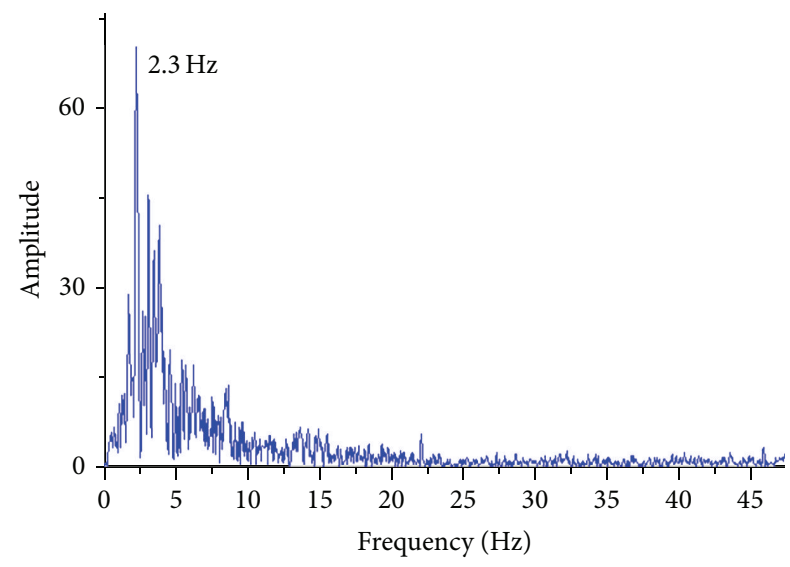

FIgURE 10: The FFT of Wolong ground motion in $X$ direction.

structural columns is calculated [18]; lateral piers stiffness of masonry structure with structural columns is calculated $[19,20]$; the stiffness ratio of pier between windows and

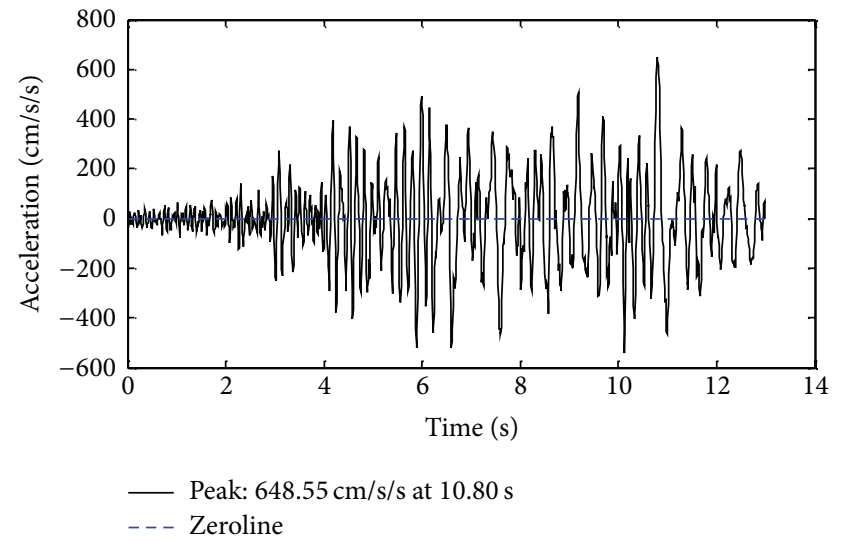

Figure 11: The time history curve of Wolong ground motion in $Y$ direction.

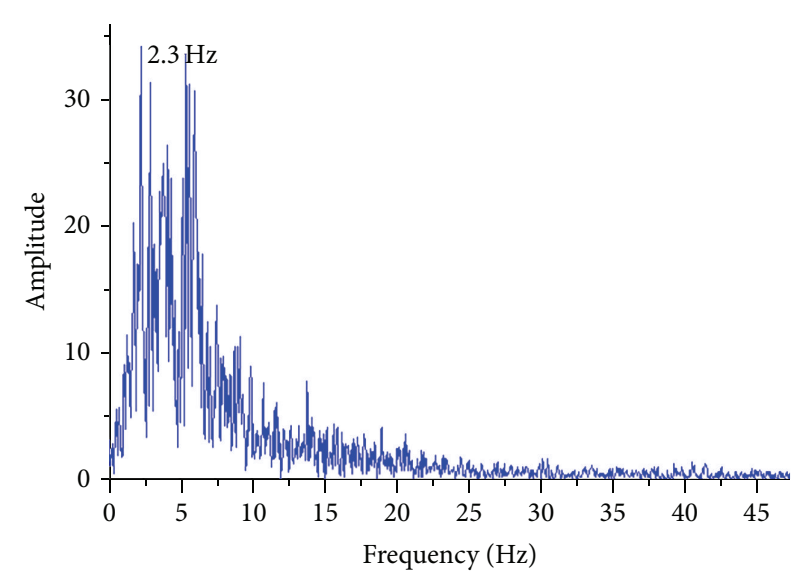

FIGURE 12: The FFT of Wolong ground motion in $Y$ direction.

spandrel is calculated $[18,21]$; and according to the models parameters, results are calculated as shown in Tables 3 and 4 . 
TABLE 4: The stiffness ratio of pier between windows and spandrel.

The stiffness ratio

The models The total stiffness of pier between windows The total stiffness of spandrel

The total pier between windows and the total spandrel

\begin{tabular}{llccc}
\hline Model 1 & 15.25 & 9.66 & 1.58 & 1.41 \\
Model 2 & 13.63 & & 1.43 & 1.51 \\
Model 3 & 18.83 & 13.20 & 1.26 & 1.58 \\
Model 4 & 16.59 & & 2.12 & 1.32 \\
Model 5 & 12.72 & 6.00 & 1.93 & 2.35 \\
Model 6 & 11.60 & & 2.10 \\
\hline
\end{tabular}

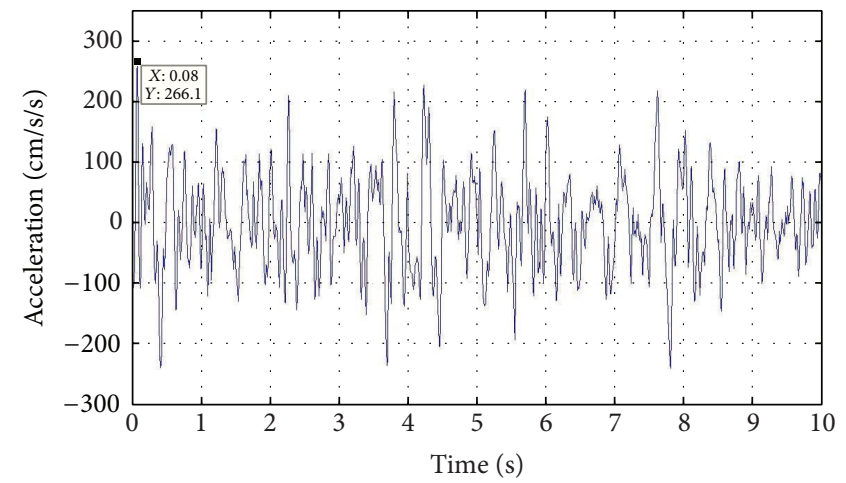

FIGURE 15: The time history curve of Lixian County ground motion in $Y$ direction.

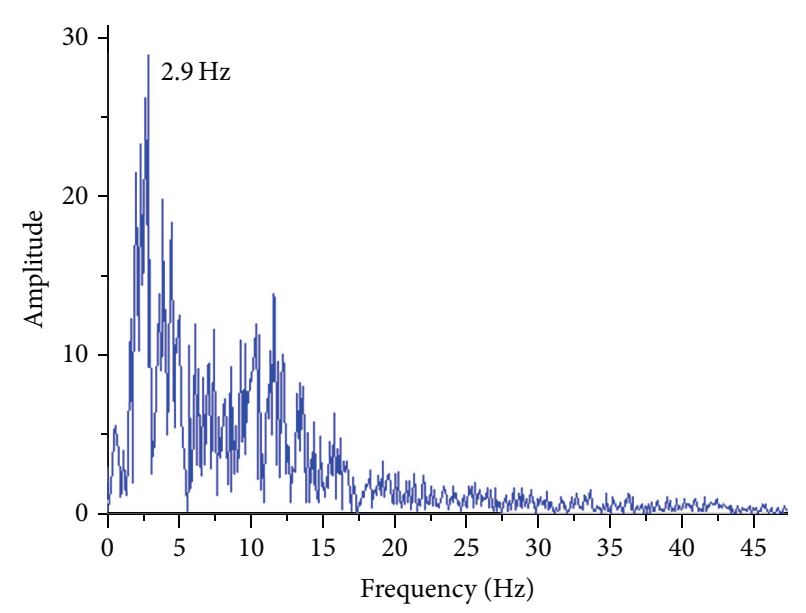

FIGURE 16: The FFT of Lixian County ground motion in $Y$ direction.

The stiffness ratio of pier between windows and spandrel increases with the spandrel height decrease.

(1) The Analysis from Tension Crack Damage Cloud. The final calculation results of model 6 , model 2 , and model 4 under Lixian County ground motion are shown in the tension crack damage cloud, in Figures 17, 18, and 19. The final calculation results of model 6 , model 2 , and model 4 under Wolong ground motion are shown in the tension crack damage cloud, in Figures 20, 21, and 22. To facilitate observation and 


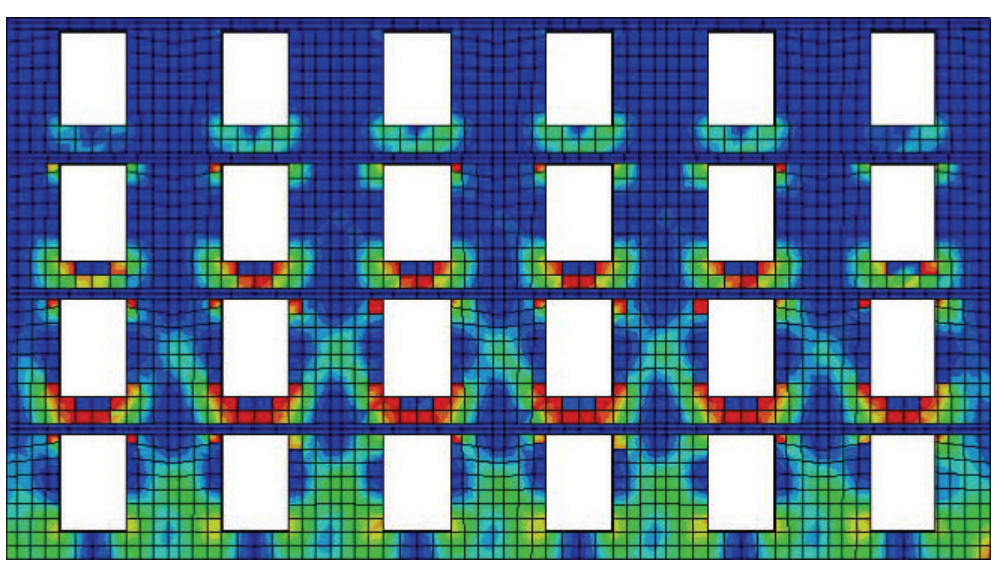

Damaget (avg.: 75\%)

FIgURE 17: Tension crack damage cloud of model 6 under Lixian County ground motion.
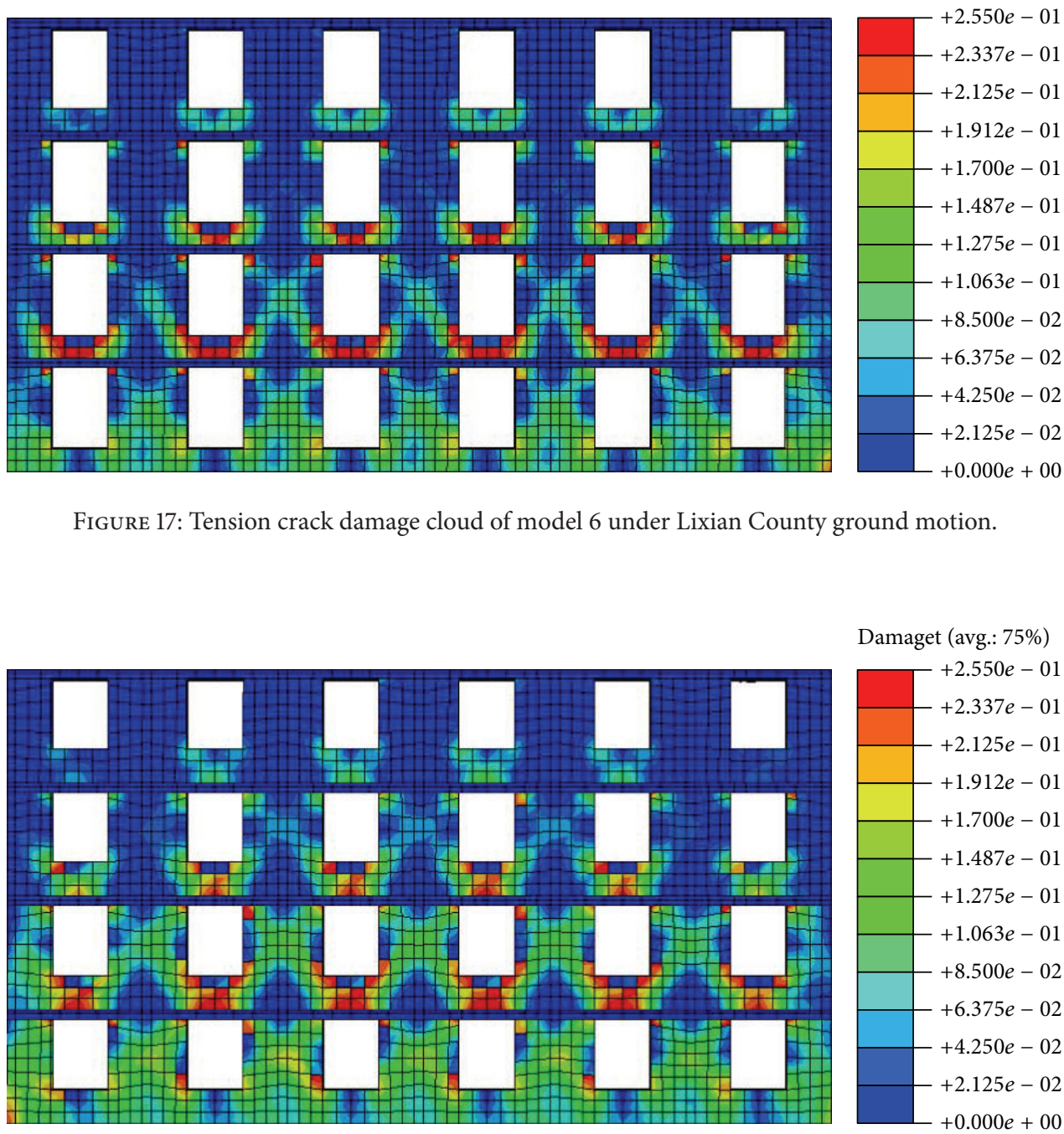

Damaget (avg.: 75\%)

FIGURE 18: Tension crack damage cloud of model 2 under Lixian County ground motion.
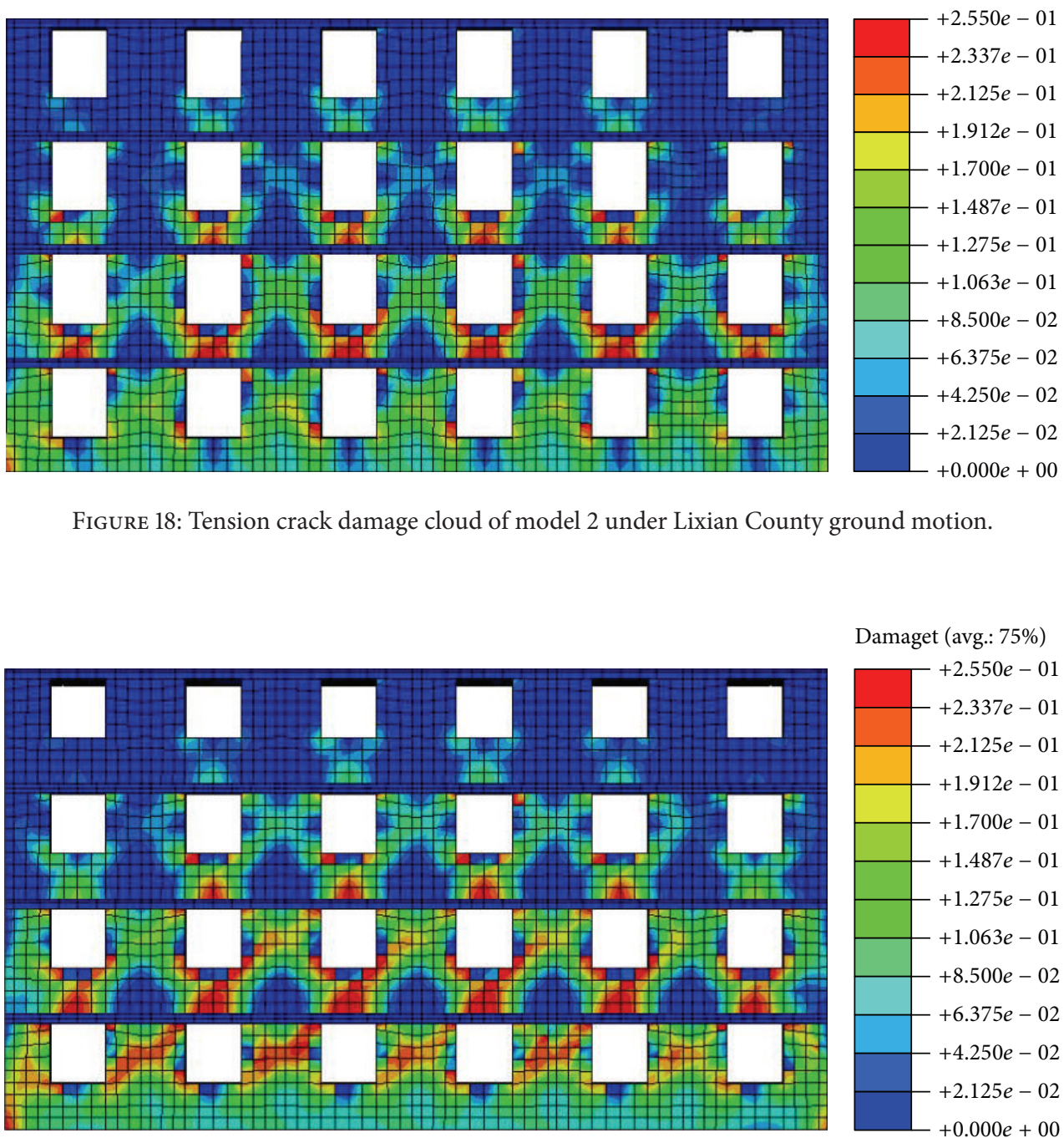

Damaget (avg.: 75\%)

FIGURE 19: Tension crack damage cloud of model 4 under Lixian County ground motion.

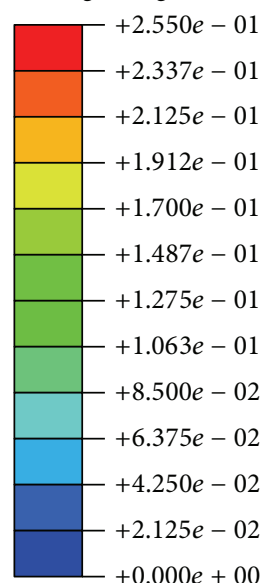



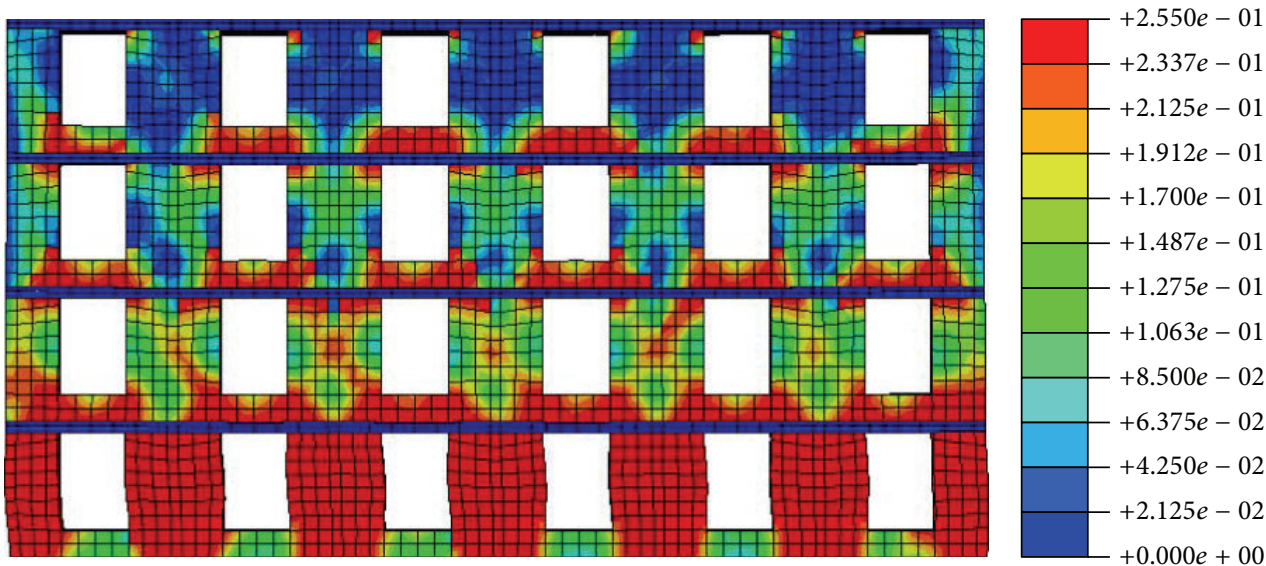

FIGURE 20: Tension crack damage cloud of model 6 under Wolong ground motion.

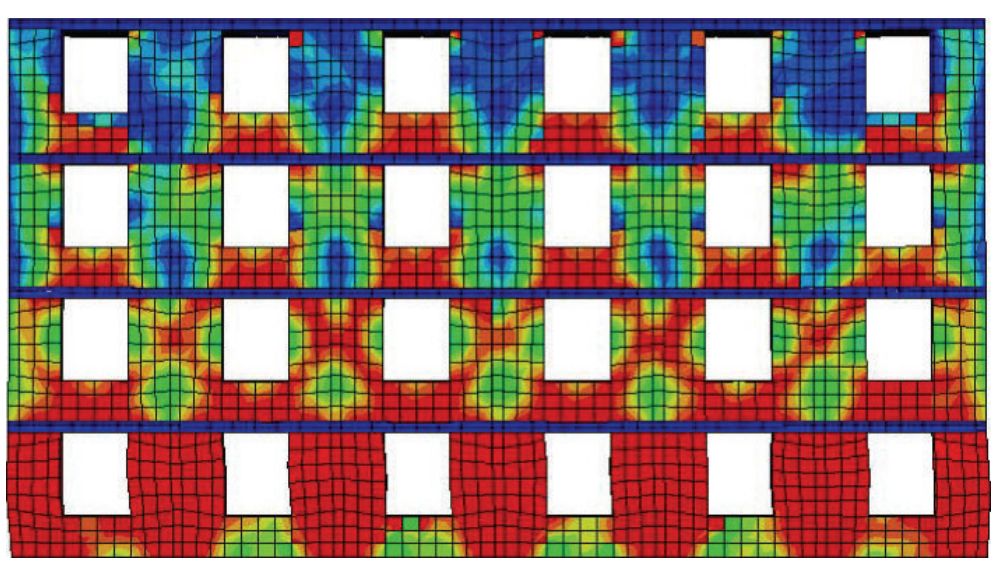

Damaget (avg.: 75\%)

FIGURE 21: Tension crack damage cloud of model 2 under Wolong ground motion.

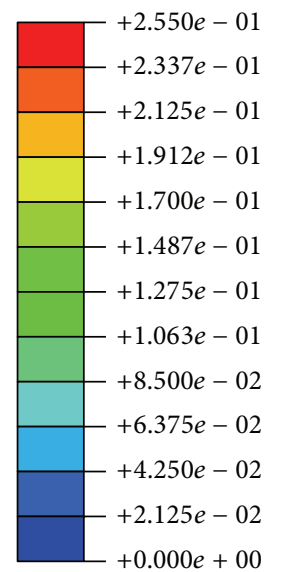

Damaget (avg.: 75\%)
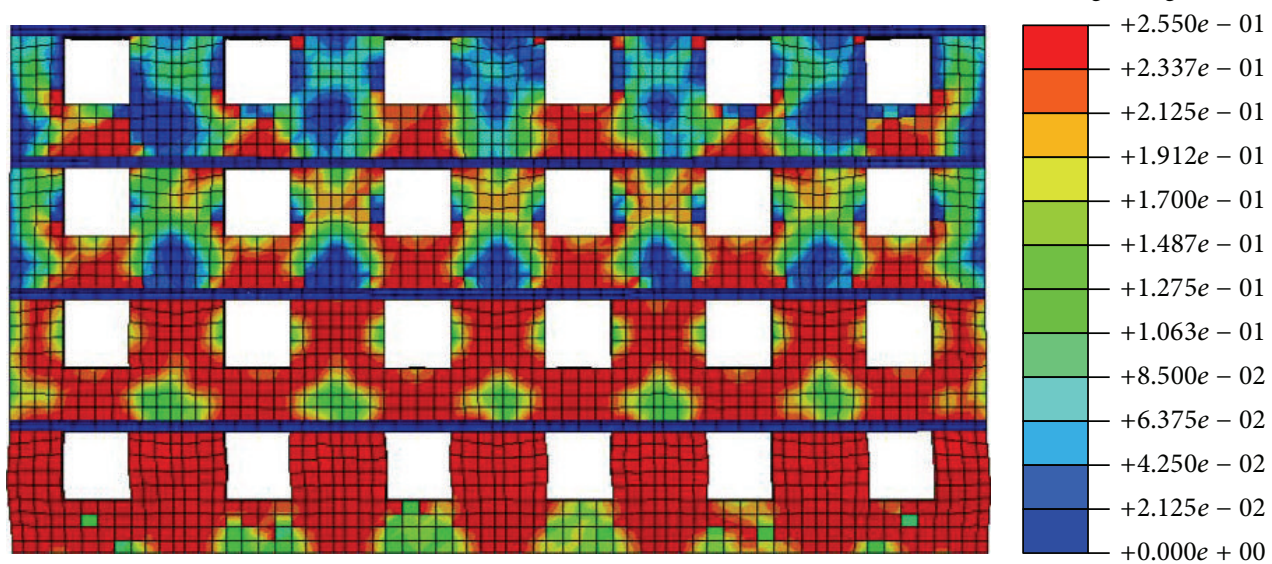

FIGURE 22: Tension crack damage cloud of model 4 under Wolong ground motion. 

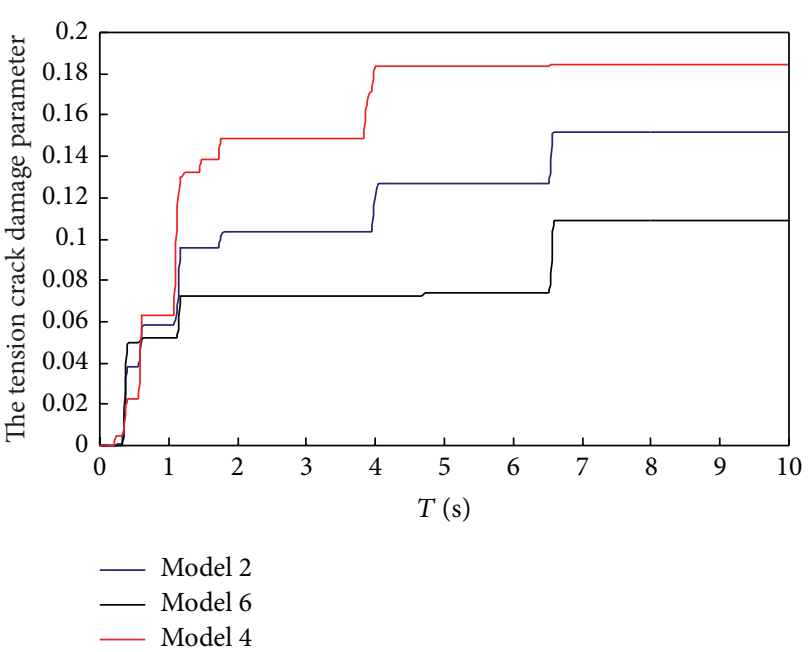

Figure 23: The tension crack damage parameter of pier between windows under Lixian County ground motion.

comparison, only one vertical pier with window opening is given.

From tension crack damage cloud under two ground motions, when it is in the same conditions, piers between window of model 4 suffer the heaviest damage, with the maximum height of spandrel and the minimum stiffness ratio of pier between windows and spandrel; otherwise, piers between window of model 4 suffer the lightest damage, with the minimum height of spandrel and the maximum stiffness ratio of pier between windows and spandrel; piers between window of model 2 suffer damage the middle with the middle parameters. It is obvious that the destruction of piers between windows becomes light from the bottom to the top of masonry structure. From three models, the damage extent of spandrel is heavier than that of pier between windows. It is clearly shown that the damage extent of masonry structures is heavier under Wolong ground motion with the bigger PGA than Lixian County ground motion.

(2) The Analysis from Time History Curve of Tension Crack Damage Parameter. The tension crack damage parameters at the same location of piers between window or spandrel in models 6, 2, and 4 are calculated under Lixian County and Wolong ground motion. The time history curve of tension crack damage parameter is shown in Figures 23, 24, 25, and 26. And the time history curve for tension crack damage parameter ratio of pier between windows and spandrel is shown in Figures 27 and 28.

From the time history curve of tension crack damage for pier between windows and the time history curve for tension crack damage parameter ratio of pier between windows and spandrel of models 6,2 , and 4 , in the same conditions, with the increase of the stiffness ratio of pier between windows and spandrel, the damage degree for piers between windows is gradually reduced. Accordingly, the structural failure mode is gradually transformed from heavy damage of pier between windows and spandrel into the damage degree of pier between windows significantly lighter than that of

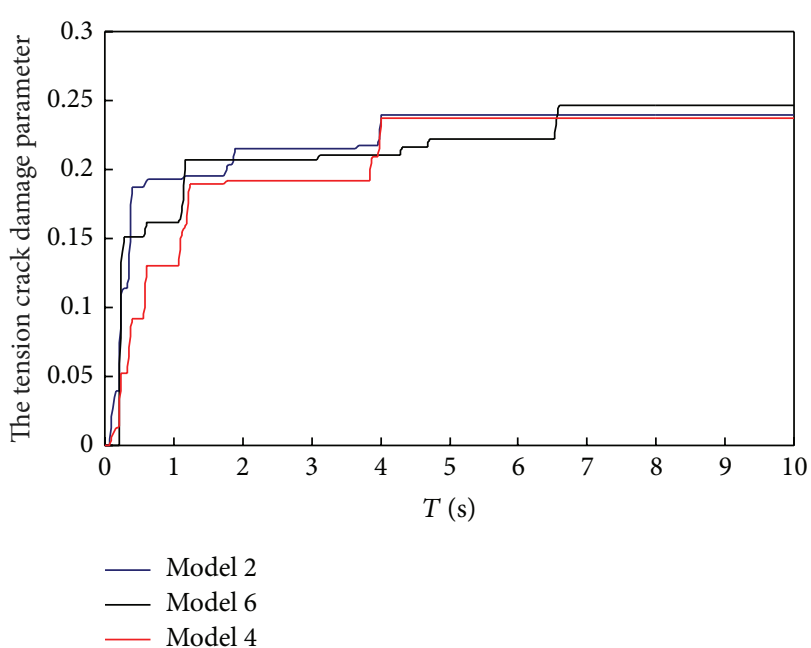

FIGURE 24: The tension crack damage parameter of spandrel under Lixian County ground motion.

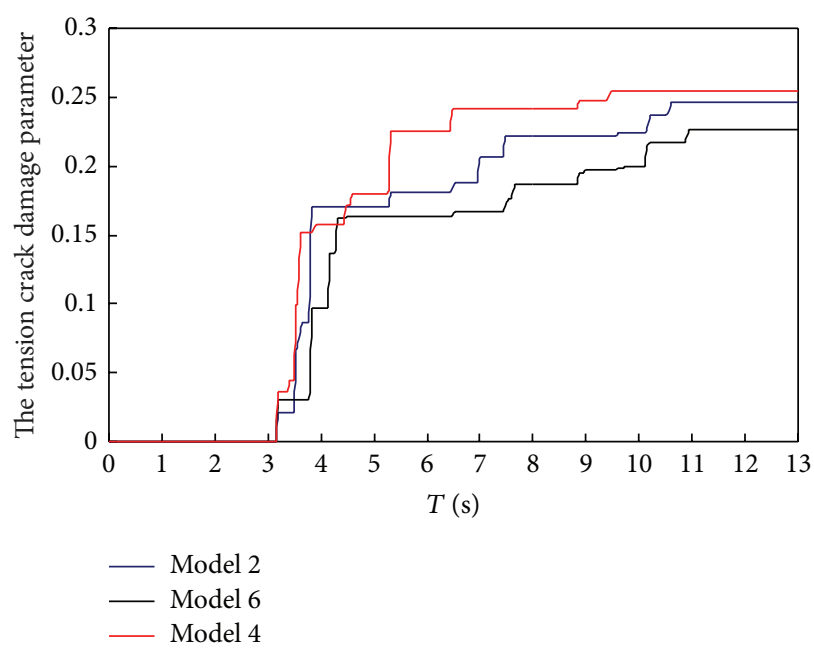

FIGURE 25: The tension crack damage parameter of pier between windows under Wolong ground motion.

spandrel. The time history curve of tension crack damage for spandrel is shown that the spandrel of three models, as weak areas in masonry structure, all suffers severely damage; and the extent of the damage is not the great difference.

Time history curves of tension crack damage for pier between windows and time history curves for tension crack damage parameter ratio of pier between windows and spandrel of models 6,2 , and 4 are also shown that when the structure was destroyed, the time with the pier within windows serious damage appearing is lag compared to that of spandrel; and the phenomenon becomes more obvious with the increase of the stiffness ratio of pier between windows and spandrel. What is more, the time with the pier between windows beginnings to be damaged is also lag compared to that of the spandrel; especially under Wolong ground motion with the obvious peak region, this phenomenon is more pronounced. In addition, with respect to pier between 


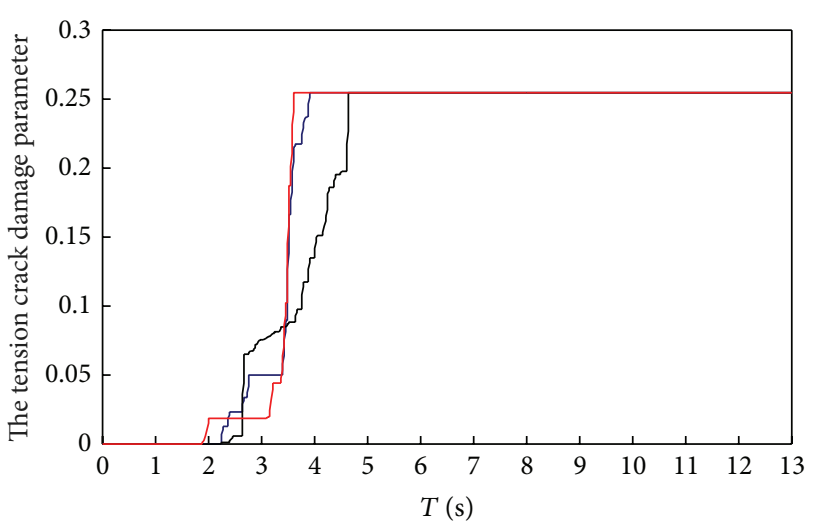

Model 2
- Model 6
- Model 4

FIGURE 26: The tension crack damage parameter of spandrel under Wolong ground motion.

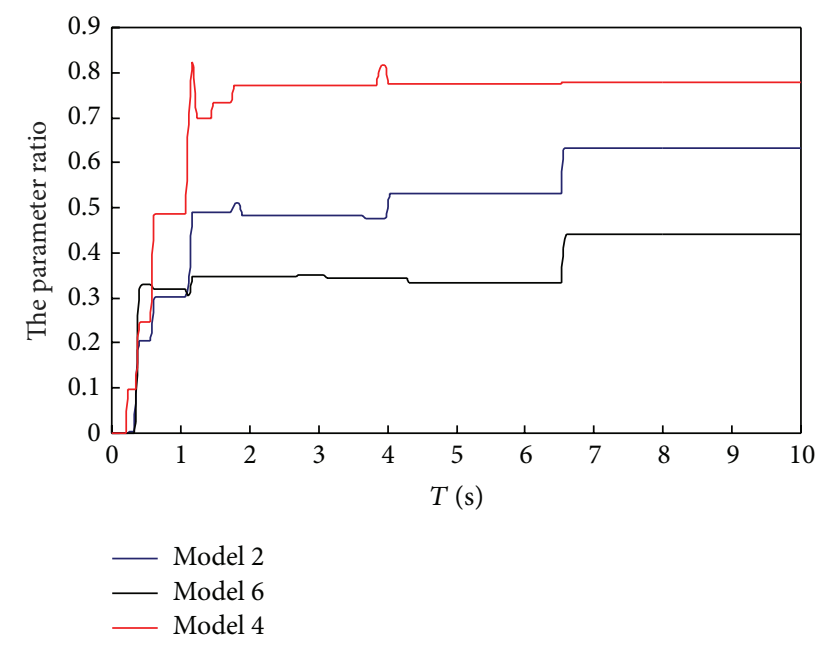

FIgURE 27: The parameter ratio of pier between windows and spandrel under Lixian County ground motion.

windows, spandrel, which is characterized by brittle fracture, becomes more apparent.

3.3.2. Analysis on the Model with Structural Columns. The spandrel height of model 5, model 1 , and model 3 is, respectively, $0.6 \mathrm{~m}, 0.9 \mathrm{~m}$, and $1.2 \mathrm{~m}$. Accordingly, the ratio of the total horizontal lateral stiffness of pier between windows and the total vertical stiffness of spandrel is, respectively, 2.12, 1.58 , and 1.43; also, the ratio of one piece horizontal lateral stiffness of pier between windows and one piece vertical stiffness of spandrel is, respectively, 2.35, 1.76, and 1.58. In the model with structural columns, the stiffness ratio of pier between windows and spandrel increases with the spandrel height decrease.

(1) The Analysis from Tension Crack Damage Cloud. The final calculation results of model 5 , model 1 , and model 3 under $\mathrm{Li}$

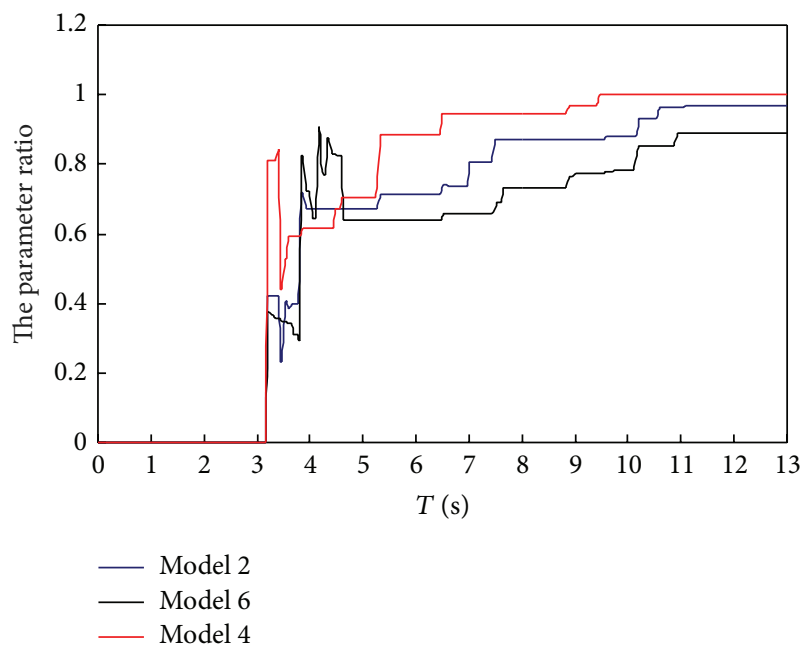

FIGURE 28: The parameter ratio of pier between windows and spandrel under Wolong ground motion.

County and Wolong ground motion are shown in the tension crack damage cloud, in Figures 29, 30, 31, 32, 33, and 34. To facilitate observation and comparison, only one vertical pier with window opening is given.

From tension crack damage cloud of models 5, 1, and 3 under Lixian County and Wolong ground motions, when being in the same conditions, masonry structure with structural columns shows the same law that the destruction extent of pier between windows gradually becomes light as the stiffness ratio of pier between windows and spandrel increases. It is also shown the rule that the destruction of piers between windows become light from the bottom to the top of masonry structure.

(2) The Analysis from Time History Curve of Tension Crack Damage Parameter. The tension crack damage parameters at the same location of piers between window and spandrel in models 5, 1, and 3 are calculated under Lixian County and Wolong ground motion. The time history curve of tension crack damage parameter is shown in Figures 35, 36, 37, and 38. And the time history curve for tension crack damage parameter ratio of piers between window and spandrel is shown in Figures 39 and 40.

From the time history curve of tension crack damage for pier between windows and the time history curve for tension crack damage parameter ratio of pier between windows and spandrel of models 5, 1, and 3, in the same conditions, with the increase of the stiffness ratio of pier between windows and spandrel, the damage degree for piers between windows is gradually reduced. Accordingly, the structural failure mode is gradually transformed from heavy damage of pier between windows and spandrel into the damage degree of pier between windows significantly lighter than that of spandrel. The time history curve of tension crack damage for spandrel is shown that the spandrel of three models, as weak areas in masonry structure, all suffers severely damage; and the extent of the damage is not the great difference. 
Damaget (avg.: 75\%)
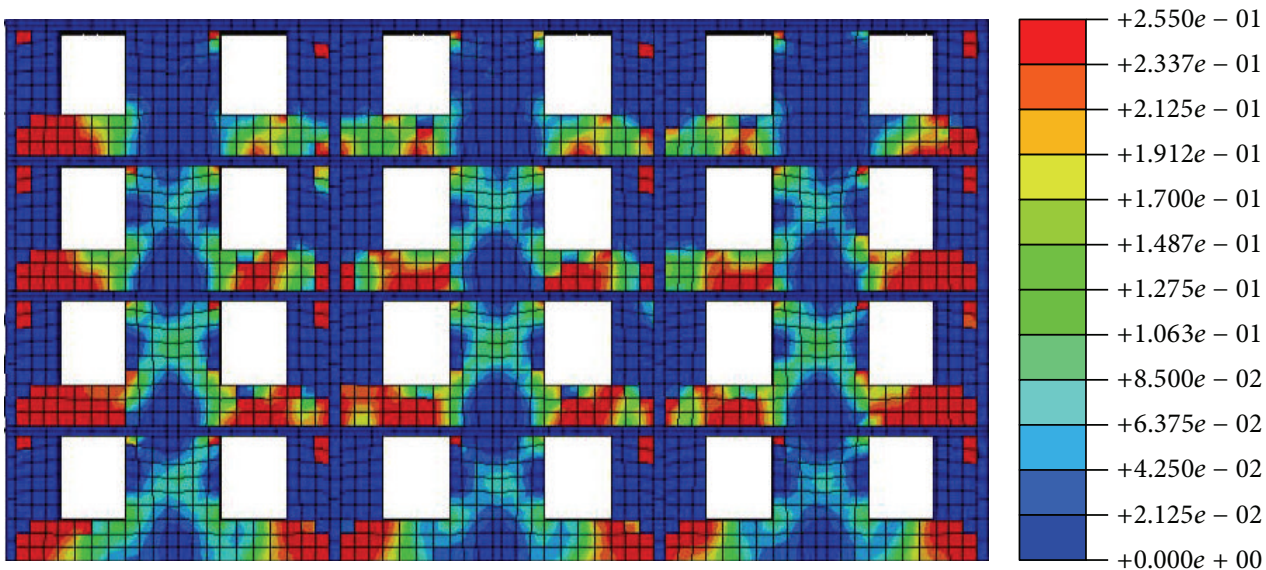

FIGURE 29: Tension crack damage cloud of model 1 under Lixian County ground motion.

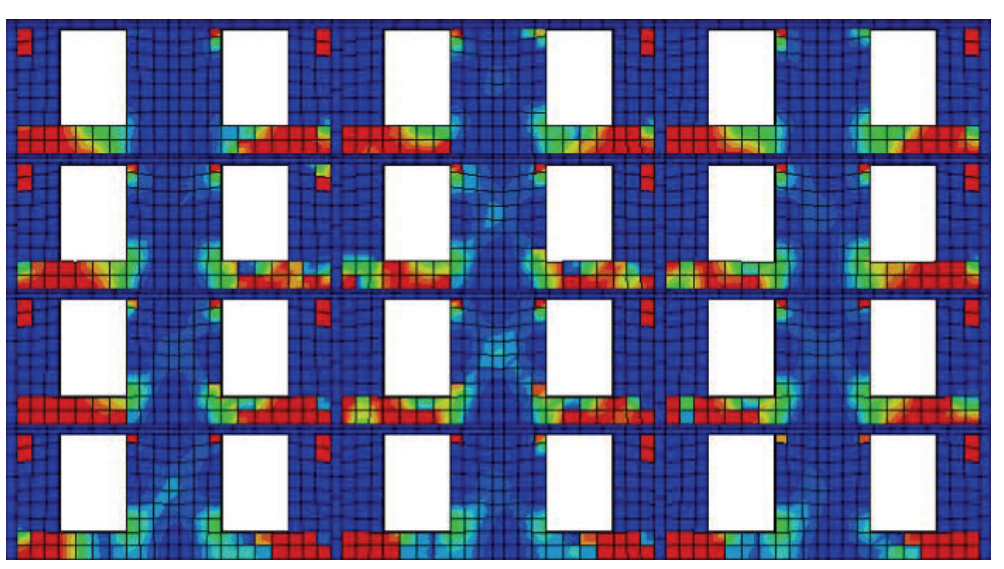

Damaget (avg.: 75\%)

FIGURE 30: Tension crack damage cloud of model 5 under Lixian County ground motion.

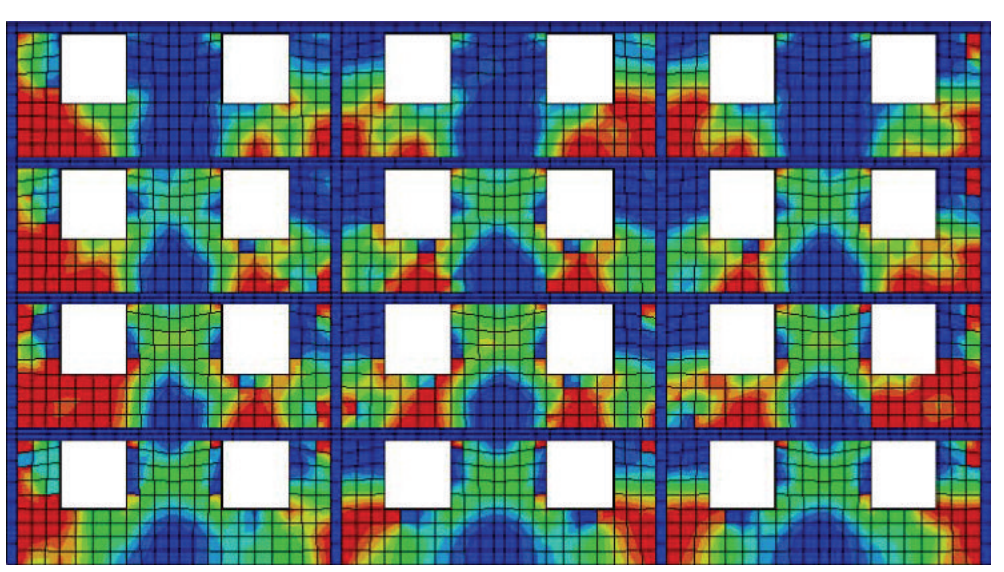

Damaget (avg.: 75\%)

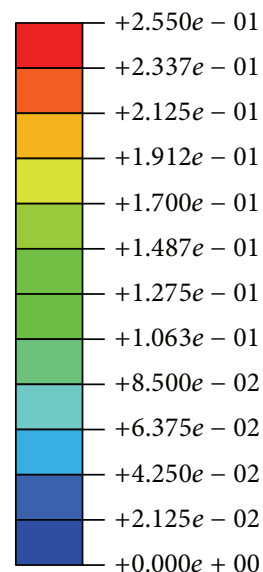

FIGURE 31: Tension crack damage cloud of model 3 under Lixian County ground motion. 
Damaget (avg.: 75\%)
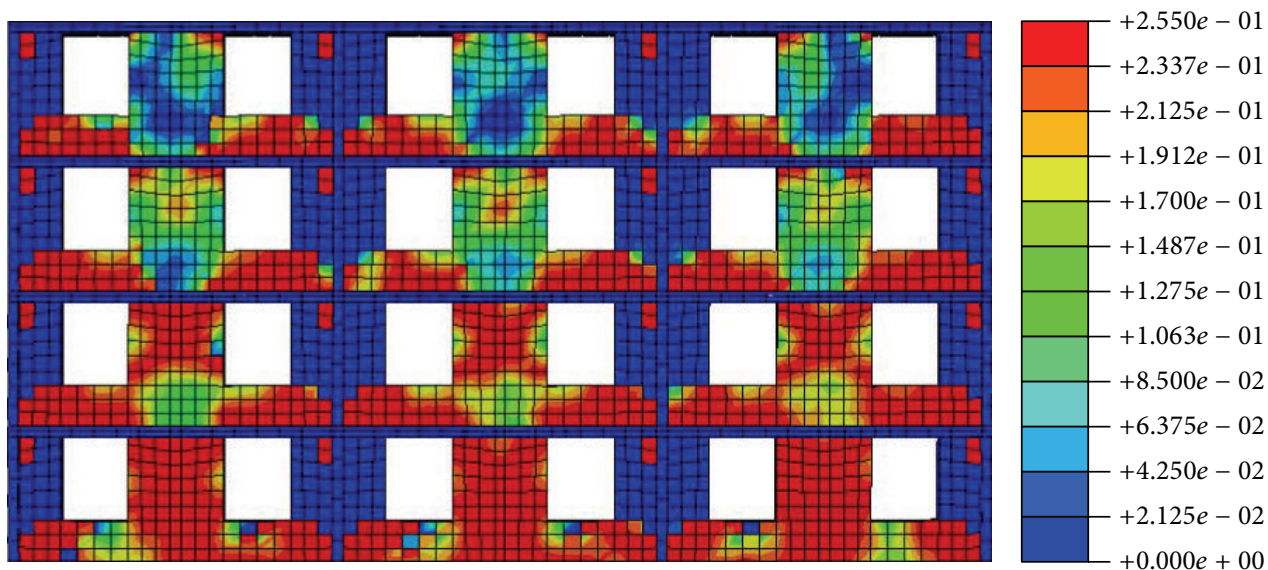

FIGURE 32: Tension crack damage cloud of model 1 under Wolong ground motion.

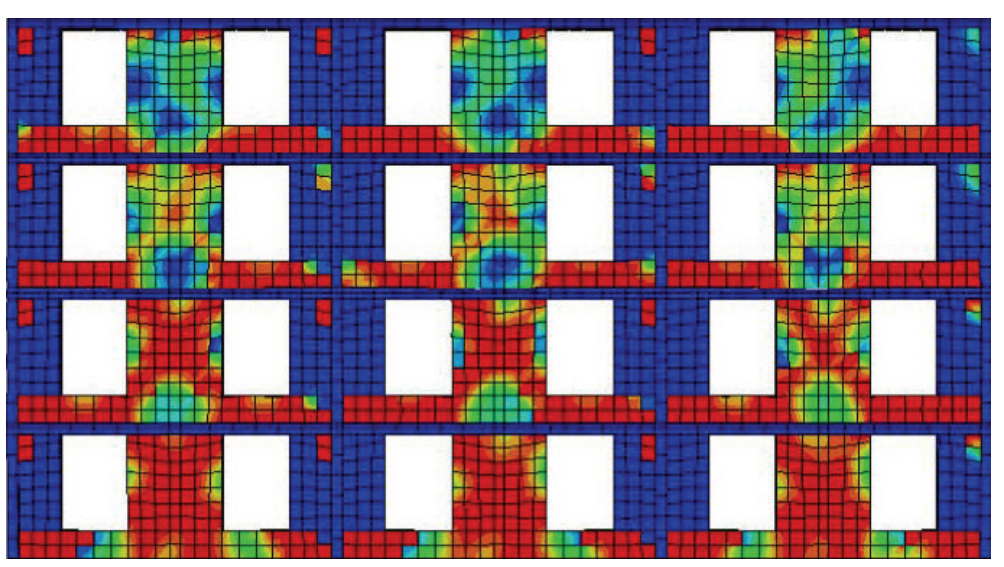

Damaget (avg.: 75\%)

FIGURE 33: Tension crack damage cloud of model 5 under Wolong ground motion.
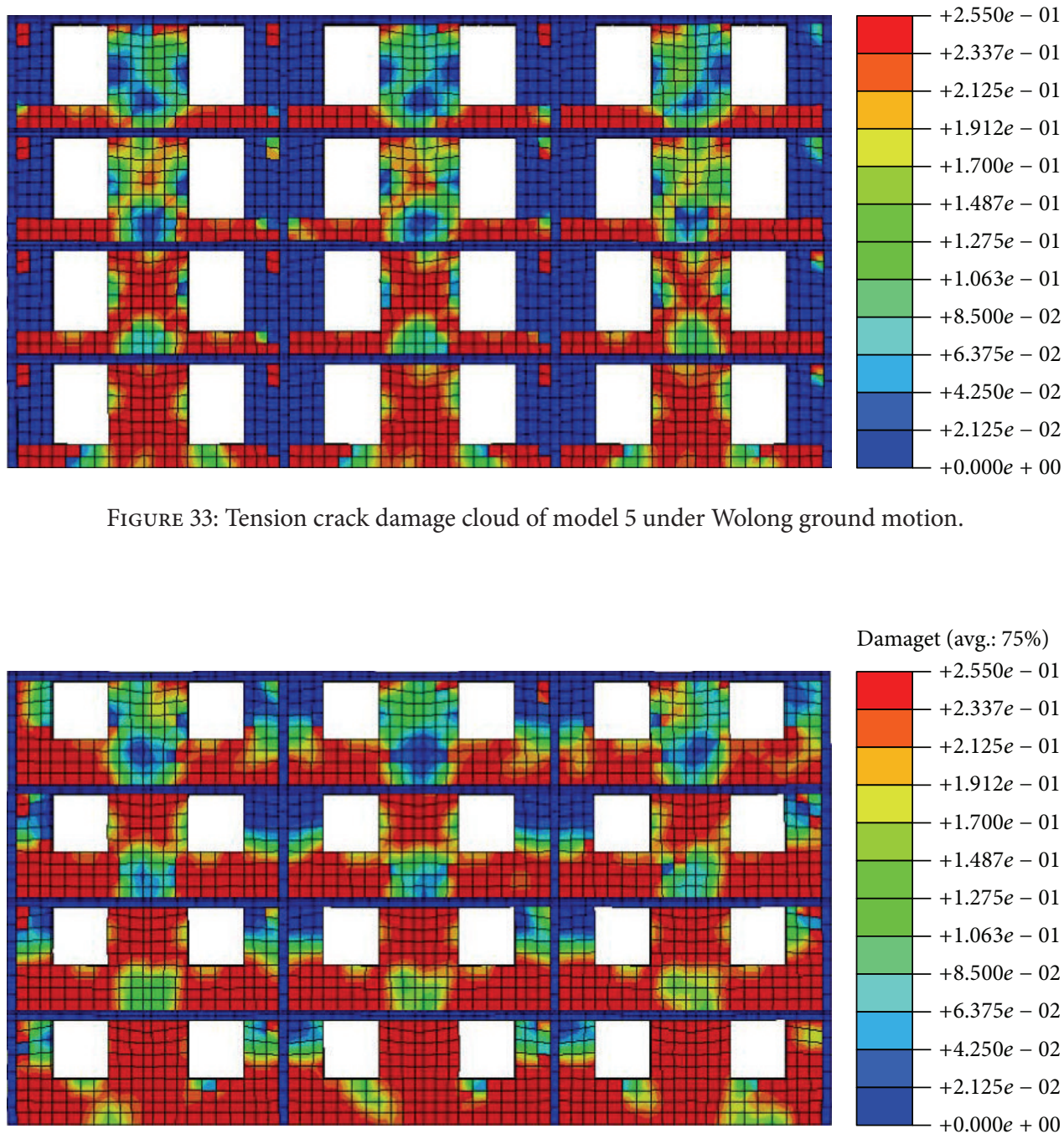

Damaget (avg.: 75\%)

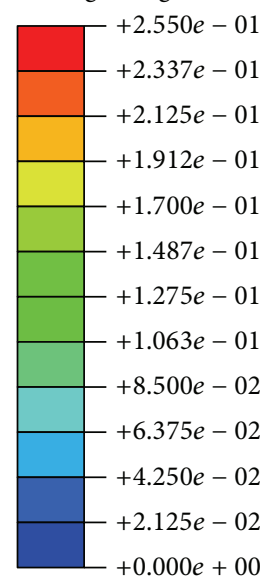

FIGURE 34: Tension crack damage cloud of model 3 under Wolong ground motion. 


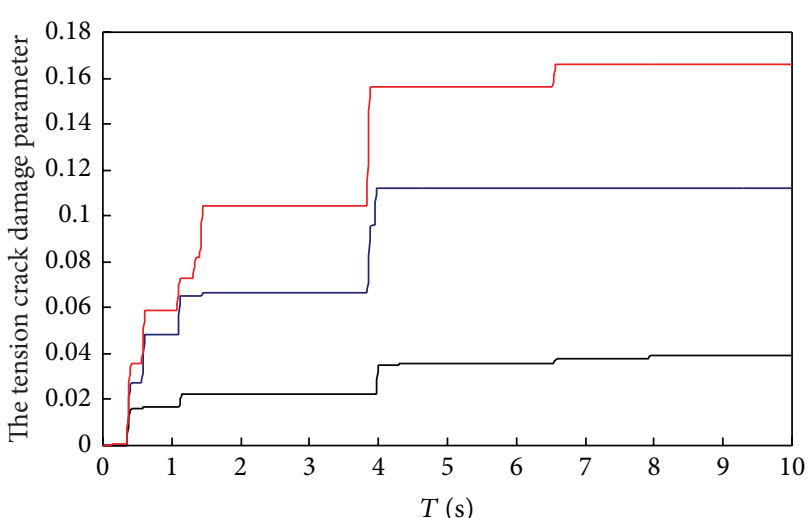

- Model 1

- Model 5

— Model 3

Figure 35: The tension crack damage parameter of pier between windows under Lixian County ground motion.

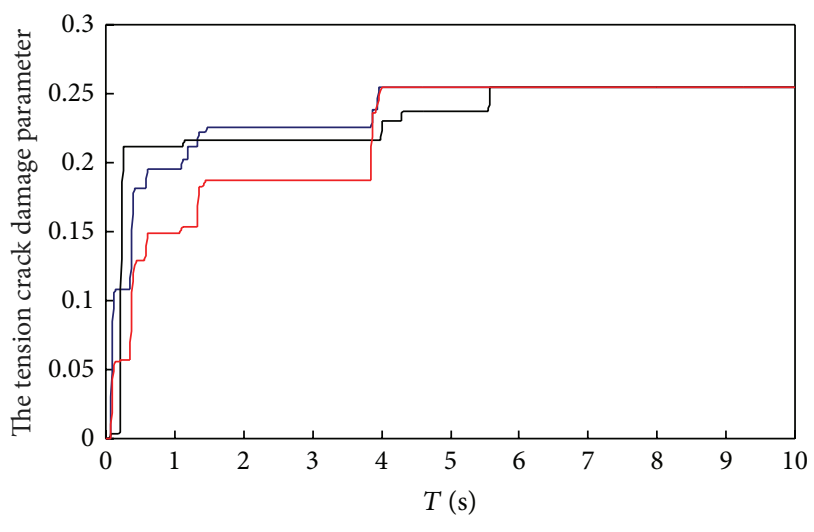

- Model 1

— Model 3

Figure 36: The tension crack damage parameter of spandrel under Lixian County ground motion.

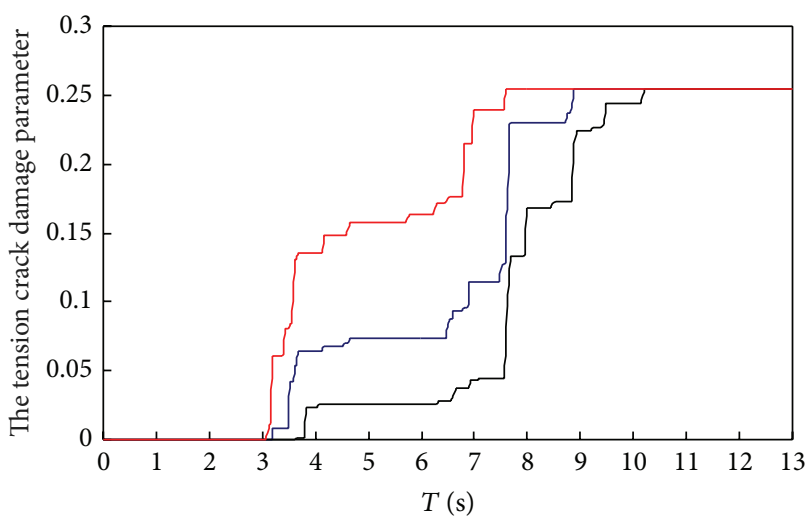

- Model 1

- Model 5

— Model 3

FIGURE 37: The tension crack damage parameter of pier between windows under Wolong ground motion.

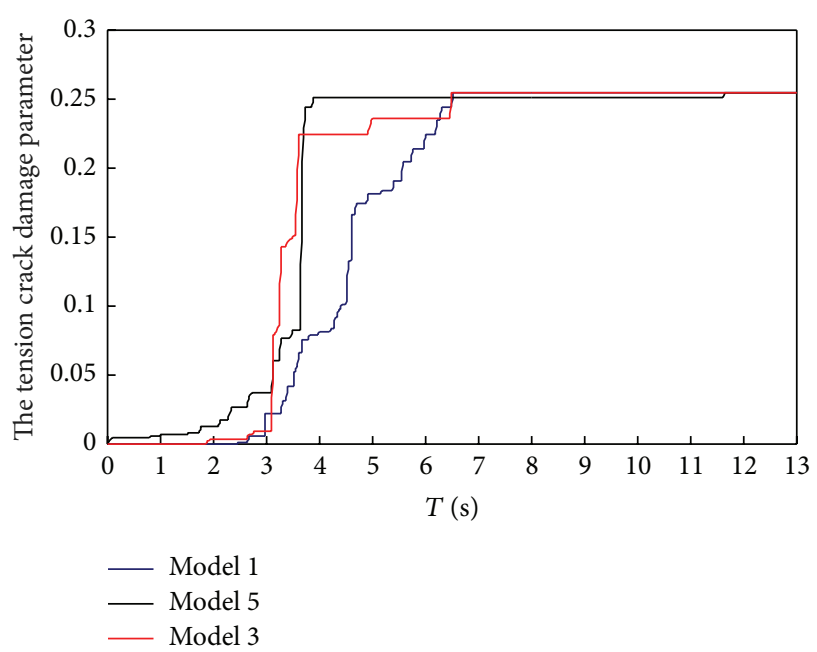

FIGURE 38: The tension crack damage parameter of spandrel under Wolong ground motion.

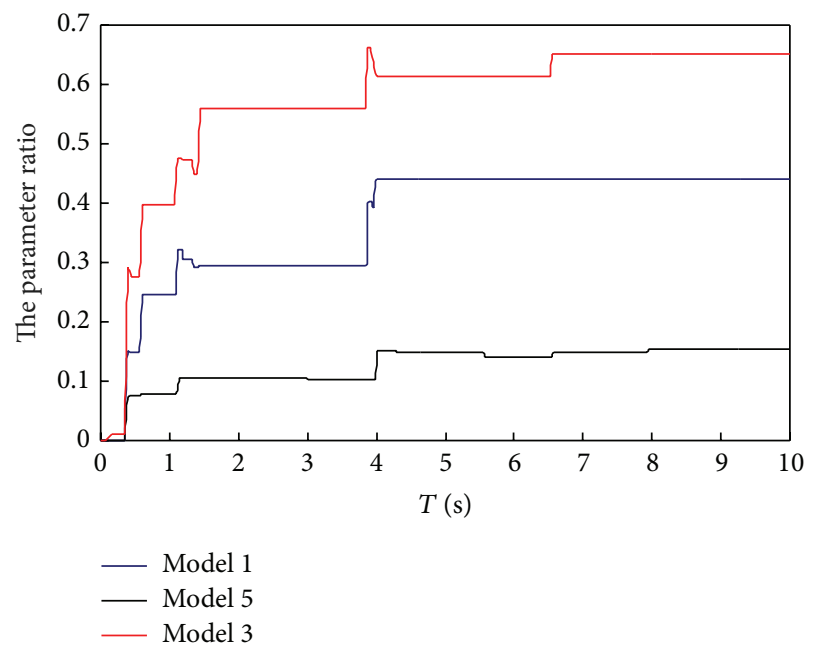

FIGURE 39: The parameter ratio of pier between windows and spandrel under Lixian County ground motion.

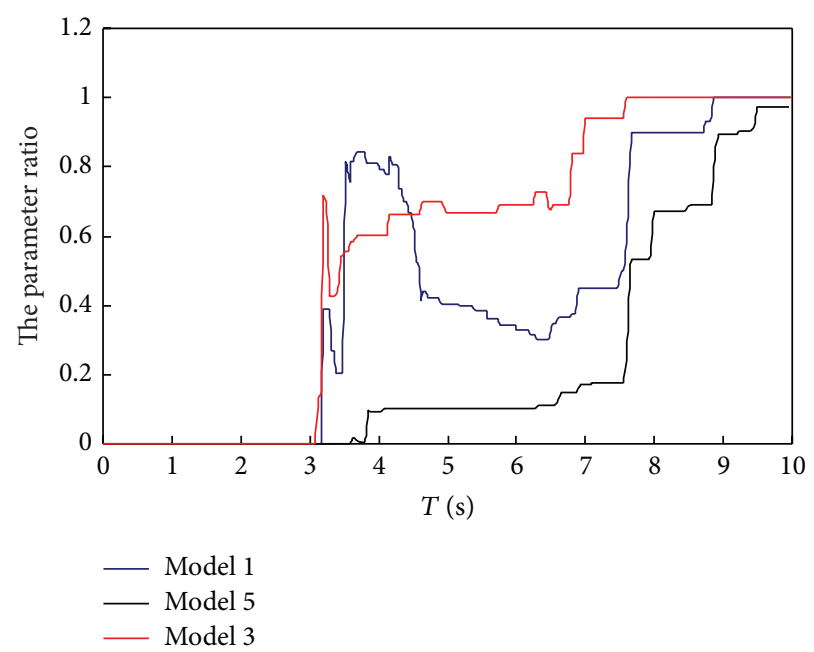

FIGURE 40: The parameter ratio of pier between windows and spandrel under Wolong ground motion. 
The masonry structure with or without structural columns shows the same laws.

Time history curves of tension crack damage for pier between windows and time history curves for tension crack damage parameter ratio of pier between windows and spandrel of models 5,1 , and 3 also show that when the structure was destroyed, the time with the pier within windows serious damage appearing is lag compared to that of spandrel; but this lag is not very different with the increase of the stiffness ratio of pier between windows and spandrel due to the structural columns of models 5,1 , and 3 . The structural columns could improve the ductility of masonry structures. Being the same as that of models 6,2 , and 4, the time with the pier between windows beginnings to be damaged is also lag compared to that of the spandrel; especially under Wolong ground motion with the obvious peak region, this phenomenon is more pronounced. In addition, with respect to pier between windows, spandrel, which is characterized by brittle fracture, becomes more apparent.

\section{Conclusions}

In this paper, as an example of Yingxiu High School Dormitory, Concrete Damaged Plasticity material models in ABAQUS software are used to calculate the structural response for each model under Lixian County and Wolong ground motions. The influence of the stiffness ratio of pier between windows and spandrel on structural response of the masonry structure is comparatively analyzed. The conclusions are as follows.

(1) The stiffness ratio of pier between windows and spandrel influences the extent of damage for pier between windows and spandrel. And damage model of masonry structures under earthquake is impacted by the ratio.

(2) With the increase of the stiffness ratio of pier between windows and spandrel, the damage degree for piers between windows is gradually reduced which are part of the vertical load-bearing components. Accordingly, the structural failure mode is gradually transformed from heavy damage of pier between windows and spandrel into the damage degree of pier between windows significantly lighter than that of spandrel. The stiffness ratio effects on the spandrel are not obvious.

(3) With the increase of the stiffness ratio of pier between windows and spandrel, the phenomenon is that the time with the pier within windows serious damage appearing obviously lags compared to that of spandrel.

(4) With the similar stiffness ratio of pier between windows and spandrel, the damage degrees of masonry structures are similar; and the failure modes of them are also similar.

\section{Conflict of Interests}

The authors declare that there is no conflict of interests regarding the publication of this paper.

\section{Acknowledgments}

The paper was supported by Zhejiang Province Natural Science Foundation Project (nos. LQ12E08006, LQ12E08007, and LY14E080018), Postdoctoral fund in China (2014M561516), Scientific Research Project in Zhejiang Province, Department of Education (Y201120696), National Natural Science Foundation of China (51208234), and Scientific Research Project, Oujiang College.

\section{References}

[1] T. Wang, Y. Lei, Y. Zhang, and Z. Kong, "Seismic damage analysis of school buildings in Lushan earthquake," Journal of Earthquake Engineering and Engineering Vibration, vol. 33, no. 3, pp. 36-47, 2013.

[2] K. Willam, A. Mohammadipour, R. Mousavi, and A. S. Ayoub, "Failure of unreinforced masonry under compression," in Proceedings of the Structures Congress, pp. 2949-2961, 2013.

[3] B. R. Banting and W. W. El-Dakhakhni, "Seismic performance quantification of reinforced masonry structural walls with boundary elements," Journal of Structural Engineering, vol. 140, no. 5, Article ID 04014001, 2014.

[4] T. Zimmermann, A. Strauss, and R. Wendner, "Old masonry under seismic loads: stiffness identification and degradation," in Proceedings of the Structures Congress, pp. 1736-1747, April 2011.

[5] China Academy of Building Research, Illustrations of Damaged Buildings after Wenchuan Earthquake, China Architecture \& Building Press, Beijing, China, 2008.

[6] Y. Chen, P. Qiao, and P. Liu, "The impact of Wenchuan earthquake on structures," Earth and Space, pp. 809-834, 2010.

[7] R. Xin and J. Yao, "Research on entire failure modes of multistorey masonry walls," World Information on Earthquake Engineering, vol. 29, no. 1, pp. 139-144, 2013.

[8] A. P. O’Donnell and Y. C. Kurama, "An analytical modeling framework for the seismic risk assessment of unreinforced masonry structures," in Proceedings of the Structures Congress, pp. 56-67, 2014.

[9] J. D. Reins, "Partial collapse of john purdue block, a historic brick masonry structure," Journal of Performance of Constructed Facilities, 2014.

[10] R. G. Drysdale and A. A. Hamid, "Tension failure criteria for plain concrete masonry," Journal of Structural Engineering, vol. 110 , no. 2, pp. 228-244, 1984.

[11] R. Ushaksaraei and S. Pietruszczak, "Failure criterion for structural masonry based on critical plane approach," Journal of Engineering Mechanics, vol. 128, no. 7, pp. 769-778, 2002.

[12] U. Andreaus, "Failure criteria for masonry panels under inplane loading," Journal of Structural Engineering, vol. 122, no. 1, pp. 37-46, 1996.

[13] C. A. Syrmakezis and P. G. Asteris, "Masonry failure criterion under biaxial stress state," Journal of Materials in Civil Engineering, vol. 13, no. 1, pp. 58-64, 2001.

[14] Z. Liu, Based Tutorial and Example Analysis of Abaqus6.6, China Water Power Press, 2008.

[15] Y. Shi and Y. Zhou, Detailed Examples of Abaqus Finite Element Analysis, Machinery Industry Press, 2008.

[16] Z. Zhuang, F. Zhuang, C. Cen, and X. You, Abaqus Non-Linear Finite Element Analysis and Examples, Science Press, Beijing, China, 2005.

[17] B. Zhou, Y. Ren, R. Wen, L. Xie, and H. Yu, "Study on EMD method in strong motion record processing application," Journal of Earthquake Engineering and Engineering Vibration, vol. 33, no. 6, pp. 9-15, 2013. 
[18] D. Tang, Masonry Structures, Higher Education Press, 2003.

[19] X. Liu, H. Zhang, J. Liu, and L. Liu, Research on Seismic Performance of Masonry Structures Strengthened by Reinforced Concrete Structural Columns, China National Knowledge Forum, 2003.

[20] X. Sun, X. Fang, and L. Guan, Mechanics of Materials, Higher Education Press, 2002.

[21] R. Zhang, "The lateral stiffness of masonry piers with openings," Guangdong Science and Technology, no. 3, pp. 16-17, 2008. 

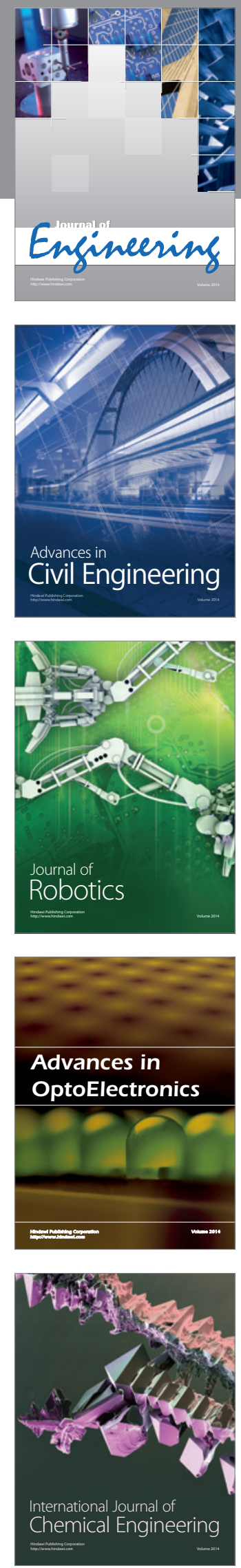

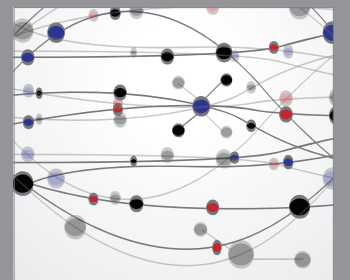

The Scientific World Journal
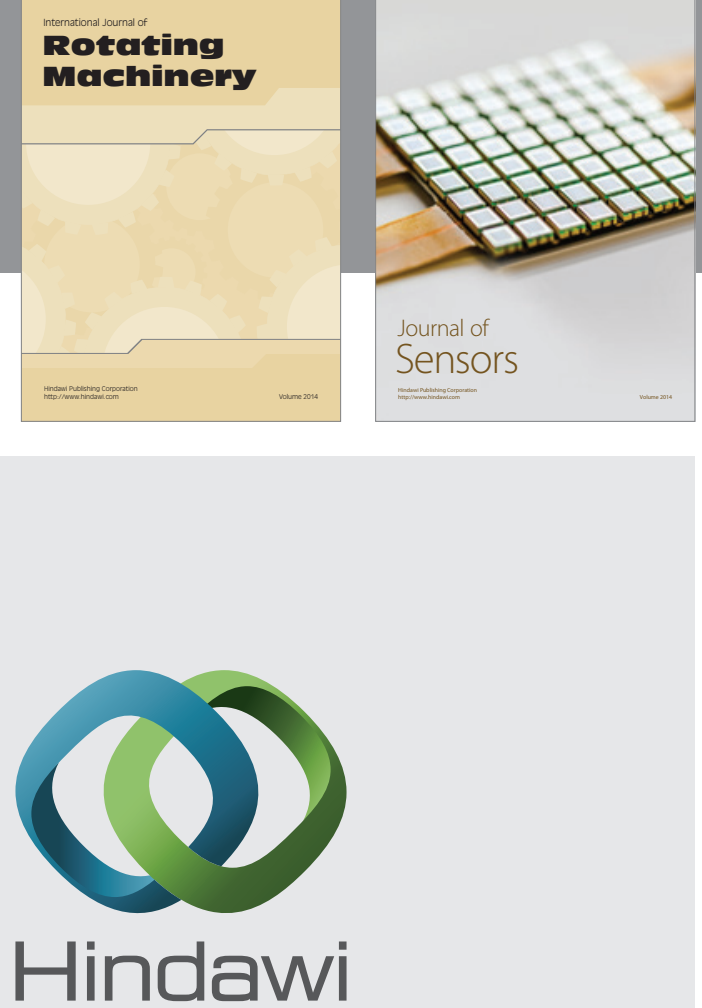

Submit your manuscripts at http://www.hindawi.com
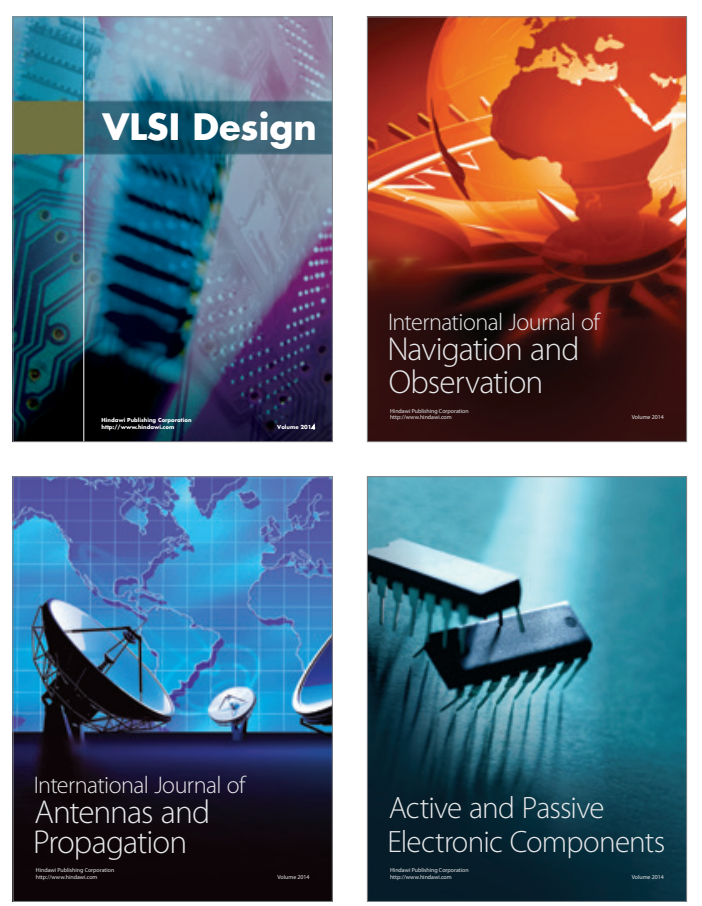
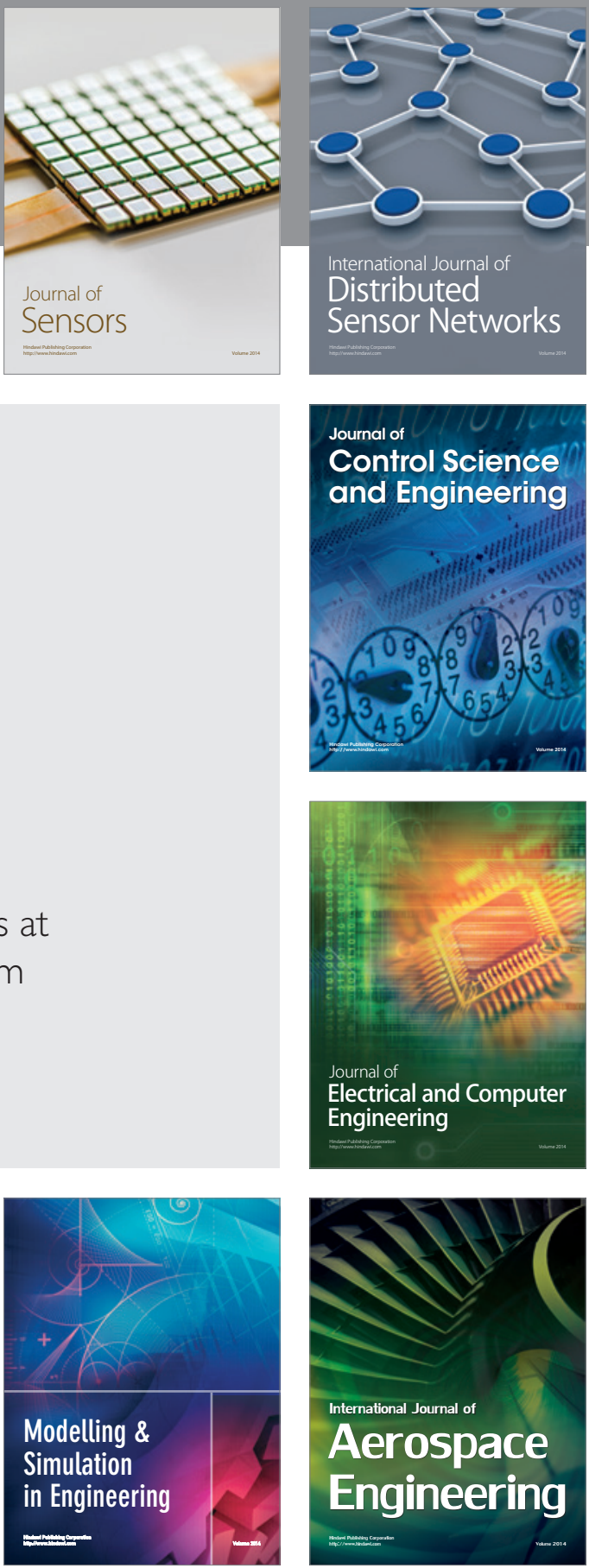

Journal of

Control Science

and Engineering
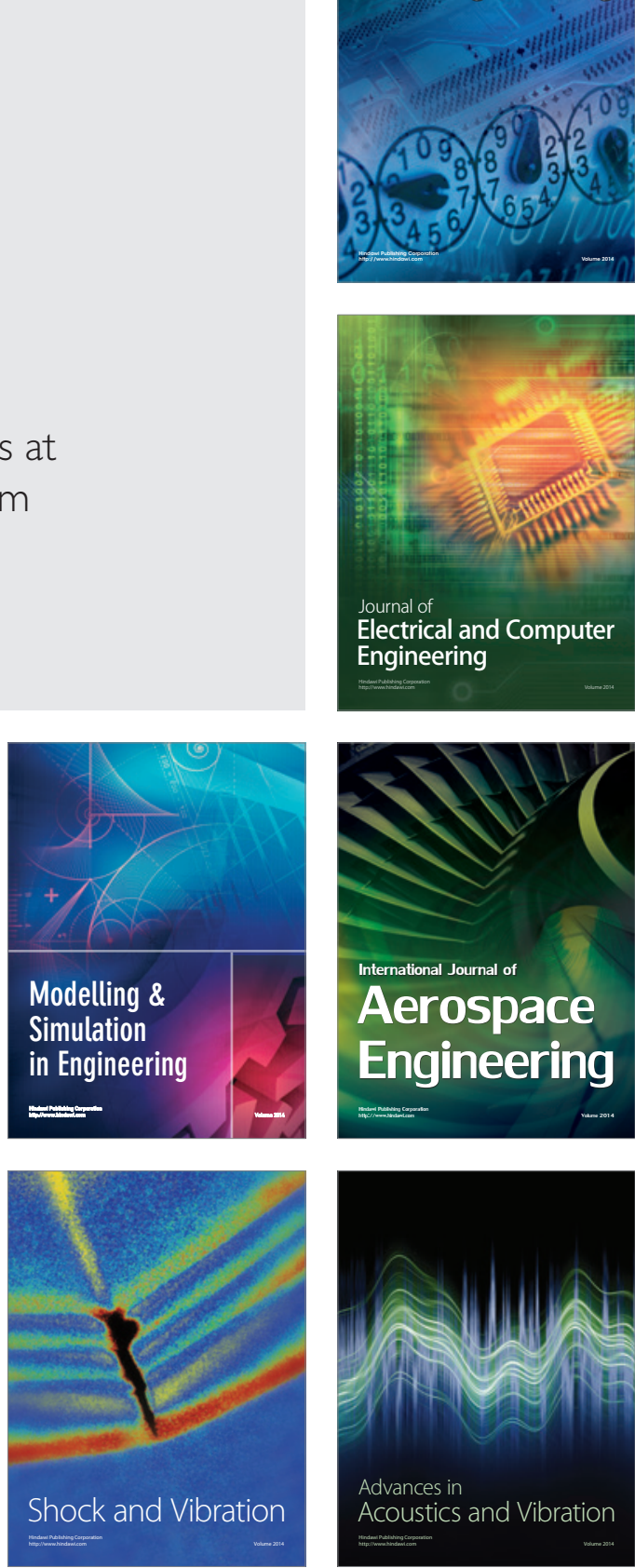